\title{
11. MELTING RELATIONS OF LEG 46 BASALTS AT ATMOSPHERIC PRESSURE
}

\author{
Hiroyuki Fukuyama, Geological Institute, Faculty of Science, University of Tokyo \\ Hongo 7-3-1, Bunkyo-ku, Tokyo, 113, Japan \\ and \\ Kazuchika Hamuro, Earthquake Research Institute, University of Tokyo
}

\section{INTRODUCTION}

Experimental studies of the melting relations of abyssal basalts are so far very few. Tilley et al. (1972) reported the liquidus temperatures of basaltic rocks including abyssal tholeiites. Kushiro and Thompson (1972) determined the phase relations of two abyssal tholeiites at high pressures, and showed that one of them (OL-tholeiite) crystallized olivine, Ca-rich and Ca-poor pyroxenes and plagioclase simultaneously at about $8 \mathrm{~kb}$. Recently, more experimental studies have been carried out (Hodges and Bender, 1976; Fujii et al., this volume). In our experimental study, we have determined the melting relations of three Leg 46 abyssal tholeiites at $1 \mathrm{~atm}$ under controlled oxygen fugacity. On the basis of these results, we discuss crystallization of abyssal tholeiite magma.

\section{EXPERIMENTAL METHOD}

The technique for sample holding is similar to that described by Presnall and Brenner (1974). A pressed powder sample about 5 to $7 \mathrm{~mm}$ in diameter is supported by a loop of platinum wire $0.05 \mathrm{~mm}$ in diameter, and is placed in a vertical furnace at $1300^{\circ} \mathrm{C}$ under controlled $\mathrm{fO}_{2}\left(10^{-8}\right.$ to $\left.10^{-10} \mathrm{~atm}\right)$ to make a homogeneous glass of teardrop shape. The glass is used as a starting material. The Fe loss during the experiment is negligible with this procedure. The furnace temperature is kept constant within $\pm 2^{\circ} \mathrm{C}$. The $\mathrm{fO}_{2}$ is controlled by a $\mathrm{CO}_{2}-\mathrm{H}_{2}$ gas mixture.

\section{STARTING MATERIALS}

The starting materials are aphyric basalts, Samples 396B-15-3, 95-100 cm and 7-3, 5-20 cm of Leg 46, described by Sato et al. (this volume). Sample 7-3, $5-20 \mathrm{~cm}$ contains a few olivine and plagioclase phenocrysts. A porphyritic basalt (Sample 22-1, 105-110 cm) with a considerable number of plagioclase phenocrysts and a small amount of $\mathrm{Cr}$-spinel, is also used as a starting material.

Shido et al. (1971) showed that the abyssal basalts with phenocrysts of olivine and those with phenocrysts of plagioclase are distinguishable in the triangular diagram ol-pl-px. The basalt having a high olivine component is named OL-tholeiite, that having a high plagioclase component PL-tholeiite. Olivine and plagioclase are thought to be the first phases to crystallize from OL-tholeiite and PL-tholeiite, respectively.

Figure 1 shows the part of the triangular diagram with normative component $\mathrm{ol}(\mathrm{fo}+\mathrm{fa}), \mathrm{pl}(\mathrm{an}+\mathrm{ab})$, and $\mathrm{px}(\mathrm{di}+\mathrm{hy})$. Solid circles show the direct calculation of normative components from the raw analytical data, and open circles show the results recalculated by assuming that the $\mathrm{FeO} /$ total $\mathrm{Fe}$ as $\mathrm{FeO}$ is 0.9 (most of the fresh chilled glass of abyssal tholeiites have this ratio). Sample 395A-8-1, $50 \mathrm{~cm}$. basalt of Leg 45 (Fujii et al., this volume) is plotted in the OL-tholeiite field, and Sample $22-1,105-110 \mathrm{~cm}$ basalt of Leg 46 is plotted in the PL-tholeiite field, whereas basalts of Samples 15-3, 95-100 $\mathrm{cm}$ and 7-3, 5-20 $\mathrm{cm}$ are plotted around the cotectic boundary line of PL- and OL- tholeiites. According to this classification, Sample $22-1,105-110 \mathrm{~cm}$ is grouped into PL-tholeiite and Samples 15-3, 95-150 cm and 7-3, 5-20 cm are intermediate between OL- and PL- tholeiites.

\section{LIQUIDUS PHASE RELATIONS}

Results of the experiments are presented in Table 1, and the phase diagrams constructed on the basis of these results are given in Figures 2, 3, and 4. The liquidus temperatures for basalts of Samples 15-3, 95-100 cm, 7-3, 5-20 cm, and $22-1,105-110 \mathrm{~cm}$ at $\mathrm{fO}_{2}$ around $10^{-8}$ are $1195^{\circ} \mathrm{C}, 1205^{\circ} \mathrm{C}$, and $1250^{\circ} \mathrm{C}$, respectively. The liquidus temperature of the Leg 45 basalt $(395 \mathrm{~A}-8-1,50 \mathrm{~cm})$ is $1215^{\circ} \mathrm{C}$ at $\mathrm{fO}_{2} 10^{-8}$ (Fujii et al., this volume). The high liquidus temperature of Sample $22-1,105-110 \mathrm{~cm}$ basalt is one of the distinguishing features.

The liquidus phase of Sample 22-1, $105-110 \mathrm{~cm}$ is plagioclase, whereas at the liquidus of Samples 15-3, $95-150 \mathrm{~cm}$ and $7-3,5-20 \mathrm{~cm}$, olivine and plagioclase crystallized almost simultaneously. Fujii et al. (this volume) reported that olivine crystallizes on the liquidus of Leg 45 basalt $(395 \mathrm{~A}-8-1,50 \mathrm{~cm})$ at $\mathrm{fO}_{2}=10^{-8}$. These liquidus phase relations are consistent with the discussion by Shido et al. (1971) that OL-tholeiite crystallizes olivine and PL-tholeiite crystallizes plagioclase at the liquidus, and that basalts with compositions along the cotectic boundary crystallize both olivine and plagioclase at lower temperatures.

However, the liquidus temperature of Sample 22-1, $105-110 \mathrm{~cm}$ basalt (PL-tholeiite) is distinctively high among the abyssal basalts with similar $\mathrm{MgO}$ content. Plagioclase phenocrysts of PL-tholeiite are sometimes corroded or mantled by more sodic rims. Fujii et al. (this volume) determined the density change of abyssal basalt melt with pressure, and demonstrated that at pressures higher than 5 $\mathrm{kb}$, plagioclase could float in the basalt melt. It follows from these results that PL-tholeiite is not originally liquid with its bulk composition, but is derived by mixing of the liquid and floating plagioclase phenocrysts. The liquid may crystallize olivine as well as plagioclase, but olivine may have sunk during migration of the magma. 


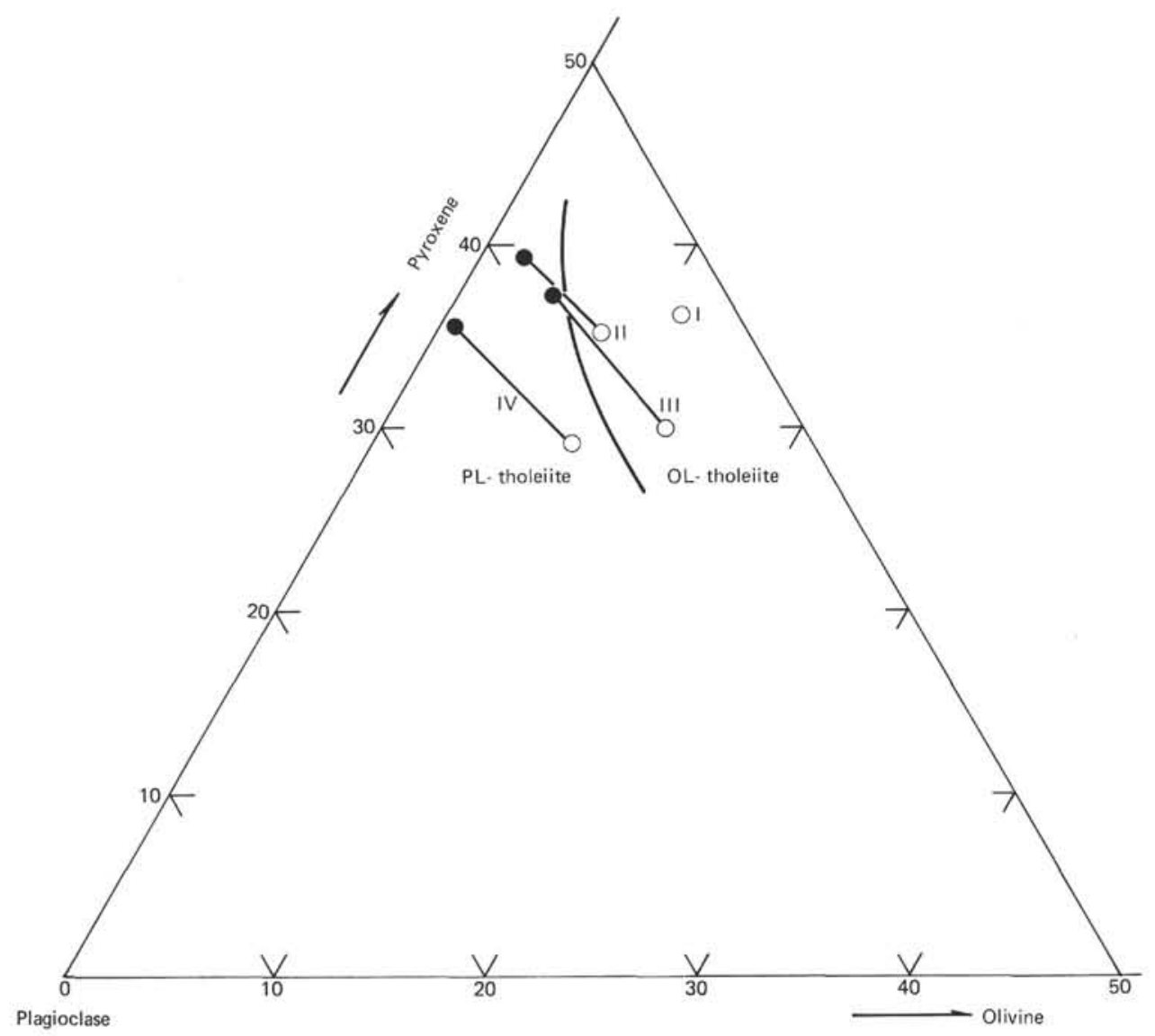

Figure 1. Normative olivine-plagioclase-pyroxene diagram. I: Leg 45-395A-8-1 9, II: Leg 46-396B-15-3, 95-150 cm, III: 396B-7-3, 5-20 cm, IV: 396B-22-1, 105-110 cm. Solid circles: normative components calculated from the raw analytical data. Open circles: recalculated results (see text). The full line represents a cotectic curve from Shido et al. (1972).

\section{CHEMICAL COMPOSITION OF OLIVINE AND PLAGIOCLASE}

\section{Olivine}

Olivine crystallized in our experiments is euhedral, and is mostly a few tens of micrometers or larger in size. Olivine crystals analyzed with the electron probe are very uniform in chemical composition. Figures 5, 6, and 7 show the Fo content of olivine in each experimental run. At constant temperature, the composition of olivine becomes Fe-rich as $\mathrm{fO}_{2}$ decreases, because the $\mathrm{FeO} / \mathrm{Fe}_{2} \mathrm{O}_{3}$ ratio in the melt increases at $\mathrm{fO}_{2}$ lower than $10^{-10}$, the composition is almost constant. It is consistent with the experimental results by Hill and Roeder (1974). At higher $\mathrm{fO}_{2}$, when iron oxide crystallizes, the composition of olivine becomes abruptly $\mathrm{Mg}$-rich. At constant $\mathrm{fO}_{2}$, the composition of olivine becomes Fe-rich with decreasing temperature by successive equilibrium crystallization.

The composition of olivine in the original rocks is reported by Sato et al. (this volume). By comparing the olivine composition with that of the experiments, the condition of $\mathrm{fO}_{2}$ at eruption of the magma can be estimated by assuming the temperature at the eruption to be near liquidus temperature. The oxygen fugacities of the magmas represented by Samples 15-3, 95-100 cm and 7-3, 5-20 cm are both about $10^{-8}$ or slightly higher.

\section{Plagioclase}

Plagioclase crystallized in the experiment is platy in most cases, and becomes thinner near liquidus temperature. Twinning is common. The composition of plagioclase varies slightly even in a single run product, partly because the electron spot may cross the boundary between plagioclase and the surrounding quenched glass during the analysis, and partly because the diffusion of elements is too slow for complete equilibrium within the experimental time. Though the complete study will be reported later, the preliminary result is shown in Figure 8. At constant temperature, the composition of plagioclase is almost constant at various $\mathrm{fO}_{2}$ conditions. With decreasing temperature, the composition of plagioclase becomes sodic by successive equilibrium crystallization. When calcic pyroxene begins to crystallize, the composition of plagioclase may be changed, but at such temperatures all crystals are too small to be analyzed even by electron probe.

The composition of plagioclase in the original rocks reported by Sato et al. (this volume) is consistent with the plagioclase crystallized nearly at the liquidus temperature, except Sample 22-1, 105-110 cm basalt. 
TABLE 1

Results of Experiments

\begin{tabular}{|c|c|c|c|}
\hline $\begin{array}{c}\text { Temperature } \\
\left({ }^{\circ} \mathrm{C}\right)\end{array}$ & $\mathrm{fO}_{2}$ & $\begin{array}{l}\text { Duration } \\
\text { (hours) }\end{array}$ & Phases \\
\hline \multicolumn{4}{|c|}{ Sample 396B-15-3, $95-100 \mathrm{~cm}$} \\
\hline 1200 & $\mathrm{CO}_{2}$ & 22 & sp, pl, liq \\
\hline 1180 & $\mathrm{OO}_{2}$ & 25 & sp, pl, ol, ilq \\
\hline 1160 & $\mathrm{CO}_{2}$ & 27 & $\mathrm{sp}, \mathrm{ol}, \mathrm{pl}, \mathrm{liq}$ \\
\hline 1150 & $\mathrm{CO}_{2}$ & 65 & $\mathrm{sp}, \mathrm{ol}, \mathrm{pl}, \mathrm{cpx}, \mathrm{liq}$ \\
\hline 1130 & $\mathrm{CO}_{2}$ & 73 & $\mathrm{sp}, \mathrm{ol}, \mathrm{pl}, \mathrm{cpx}, \mathrm{liq}$ \\
\hline 1200 & $10^{-8}$ & 18 & liq \\
\hline 1190 & $10^{-8}$ & 22 & sp, ol, pl, liq \\
\hline 1180 & $10^{-8}$ & 63 & $\mathrm{sp}, \mathrm{ol}, \mathrm{pl}, \mathrm{liq}$ \\
\hline 1170 & $10^{-8}$ & 73 & $\mathrm{sp}, \mathrm{ol}, \mathrm{pl}, \mathrm{liq}$ \\
\hline 1160 & $10^{-8}$ & 67 & $\mathrm{sp}, \mathrm{ol}, \mathrm{pl}, \mathrm{cpx}, \mathrm{liq}$ \\
\hline 1150 & $10^{-8}$ & 45 & $\mathrm{sp}, \mathrm{ol}, \mathrm{pl}, \mathrm{cpx}, \mathrm{liq}$ \\
\hline 1130 & $10^{-8}$ & 70 & $\mathrm{sp}, \mathrm{ol}, \mathrm{pl}, \mathrm{cpx}, \mathrm{liq}$ \\
\hline 1100 & $10^{-8}$ & 118 & not identified \\
\hline 1200 & $10^{-10}$ & 24 & liq \\
\hline 1180 & $10^{-10}$ & 49 & $\mathrm{sp}, \mathrm{ol}, \mathrm{pl}, \mathrm{liq}$ \\
\hline 1160 & $10^{-10}$ & 50 & $\mathrm{sp}, \mathrm{ol}, \mathrm{pl}, \mathrm{cpx}, \mathrm{liq}$ \\
\hline 1150 & $10^{-10}$ & 59 & $\mathrm{sp}, \mathrm{ol}, \mathrm{pl}, \mathrm{cpx}, \mathrm{liq}$ \\
\hline 1140 & $10^{-10}$ & 59 & $\mathrm{sp}, \mathrm{ol}, \mathrm{pl}, \mathrm{cpx}, \mathrm{liq}$ \\
\hline \multicolumn{4}{|c|}{ Sample $396 \mathrm{~B}-7-3,5-20 \mathrm{~cm}$} \\
\hline 1180 & $10^{-6.5}$ & 22 & $\mathrm{sp}, \mathrm{ol}, \mathrm{pl}, \mathrm{liq}$ \\
\hline 1140 & $10^{-6.5}$ & 71 & sp, ol, pl, cpx. liq \\
\hline 1220 & $10^{-8}$ & 27 & liq \\
\hline 1210 & $10^{-8}$ & 22 & liq \\
\hline 1200 & $10^{-8}$ & 19 & liq \\
\hline 1180 & $10^{-8}$ & 22 & ol, pl, liq \\
\hline 1160 & $10^{-8}$ & 42 & $\mathrm{sp}, \mathrm{ol}, \mathrm{pl}, \mathrm{liq}$ \\
\hline 1140 & $10^{-8}$ & 40 & $\mathrm{sp}, \mathrm{ol}, \mathrm{pl}, \mathrm{cpx} . \mathrm{liq}$ \\
\hline 1050 & $10^{-8}$ & 168 & not identified \\
\hline 1220 & $10^{-10}$ & 24 & liq \\
\hline 1200 & $10^{-10}$ & 28 & ol, pl, liq \\
\hline 1180 & $10^{-10}$ & 27 & ol, pl, liq \\
\hline 1160 & $10^{-10}$ & 43 & ol, pl, cpx, liq \\
\hline 1140 & $10^{-10}$ & 43 & ol, pl, cpx, liq \\
\hline \multicolumn{4}{|c|}{ Sample 396B-22-1, 105-110 cm } \\
\hline 1180 & $10^{-6.5}$ & 22 & $\mathrm{sp}, \mathrm{ol}, \mathrm{pl}, \mathrm{liq}$ \\
\hline 1140 & $10^{-6.5}$ & 71 & $\mathrm{sp}, \mathrm{ol}, \mathrm{pl}, \mathrm{cpx}, \mathrm{liq}$ \\
\hline 1240 & $10^{-8}$ & 23 & $\mathrm{pl}$, liq \\
\hline 1230 & $10^{-8}$ & 22 & $\mathrm{pl}, \mathrm{liq}$ \\
\hline 1220 & $10^{-8}$ & 22 & ol, pl, liq \\
\hline 1200 & $10^{-8}$ & 19 & ol, pl, liq \\
\hline 1180 & $10^{-8}$ & 22 & $\mathrm{sp}, \mathrm{ol}, \mathrm{pl}, \mathrm{liq}$ \\
\hline 1160 & $10^{-8}$ & 42 & $\mathrm{sp}, \mathrm{ol}, \mathrm{pl}, \mathrm{cpx}, \mathrm{liq}$ \\
\hline 1140 & $10^{-8}$ & 40 & $\mathrm{sp}, \mathrm{ol}, \mathrm{pl}, \mathrm{cpx}, \mathrm{liq}$ \\
\hline 1050 & $10^{-8}$ & 168 & not identified \\
\hline 1220 & $10^{-10}$ & 24 & ol, pl, liq \\
\hline 1200 & $10^{-10}$ & 28 & ol, pl, liq \\
\hline 1180 & $10^{-10}$ & 27 & $\mathrm{ol}, \mathrm{pl}, \mathrm{liq}$ \\
\hline 1160 & $10^{-10}$ & 43 & $\mathrm{ol}, \mathrm{pl}, \mathrm{cpx}, \mathrm{liq}$ \\
\hline 1140 & $10^{-10}$ & 43 & ol, pl, cpx, liq \\
\hline
\end{tabular}

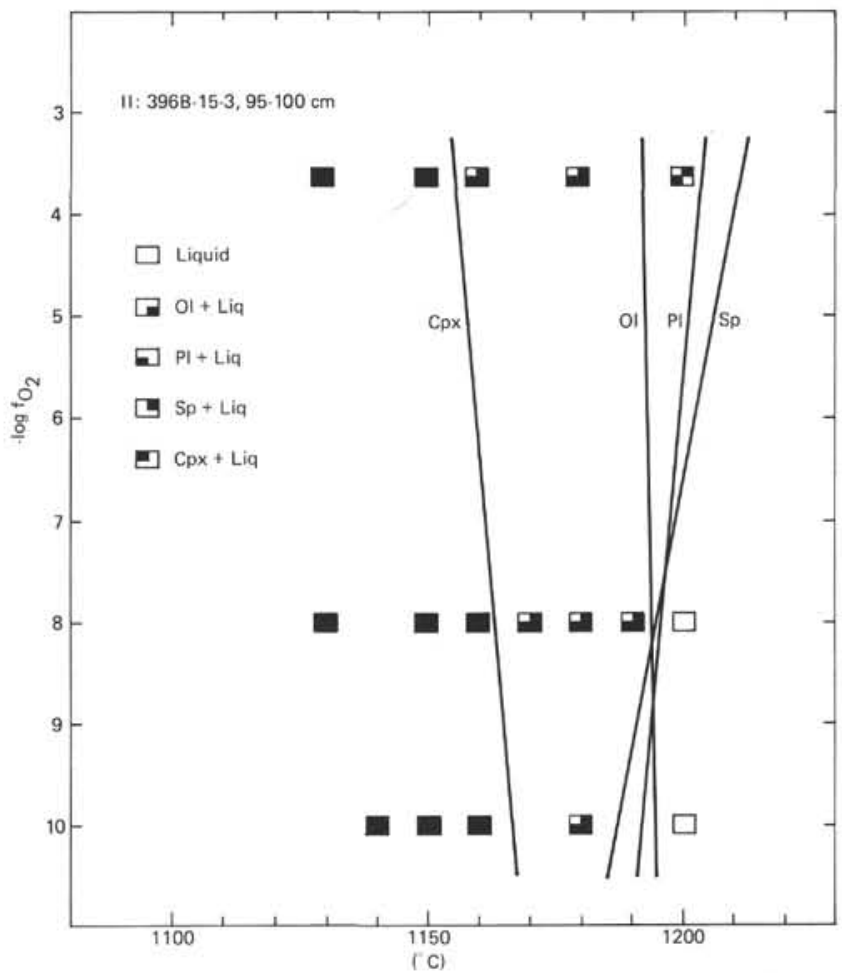

Figure 2. Temperature-fO $\mathrm{O}_{2}$ diagram for Sample 15-3, 95$100 \mathrm{~cm}$

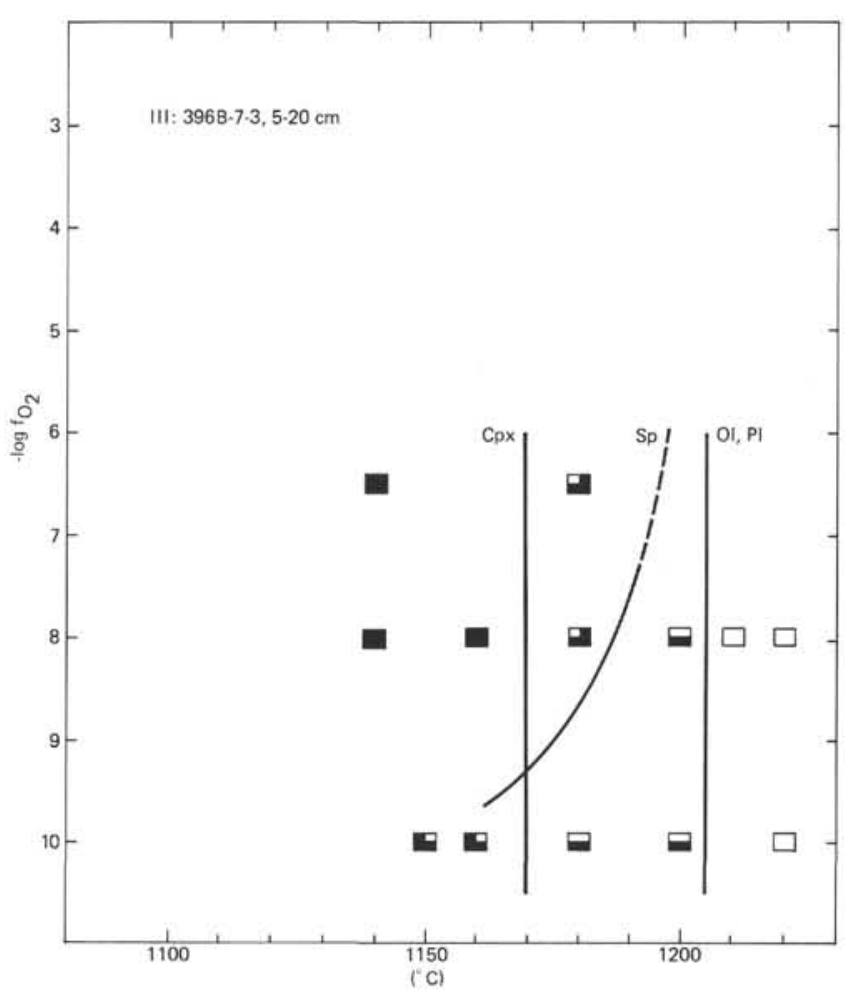

Figure 3. Temperature-fO $\mathrm{f}_{2}$ diagram for Sample 7-3, 5-20 $\mathrm{cm}$. 


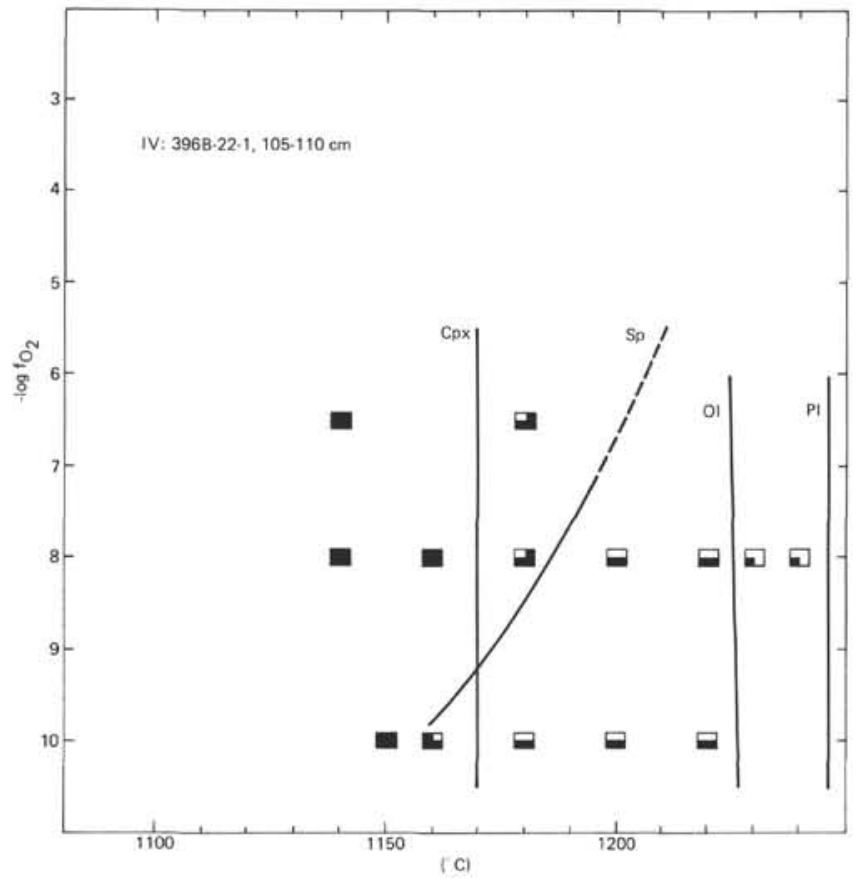

Figure 4. Temperature- $\mathrm{fO}_{2}$ diagram for Sample 22-1, 105$110 \mathrm{~cm}$.

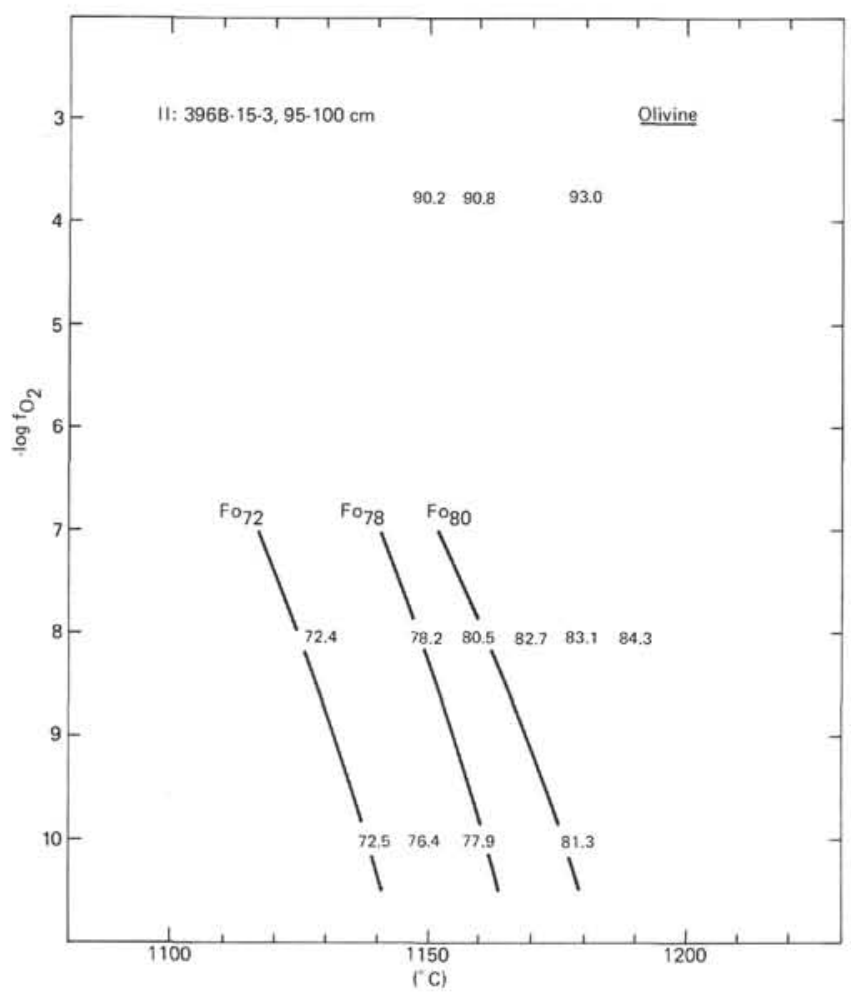

Figure 5. Composition of olivine, Sample 15-3, 95-100 cm.

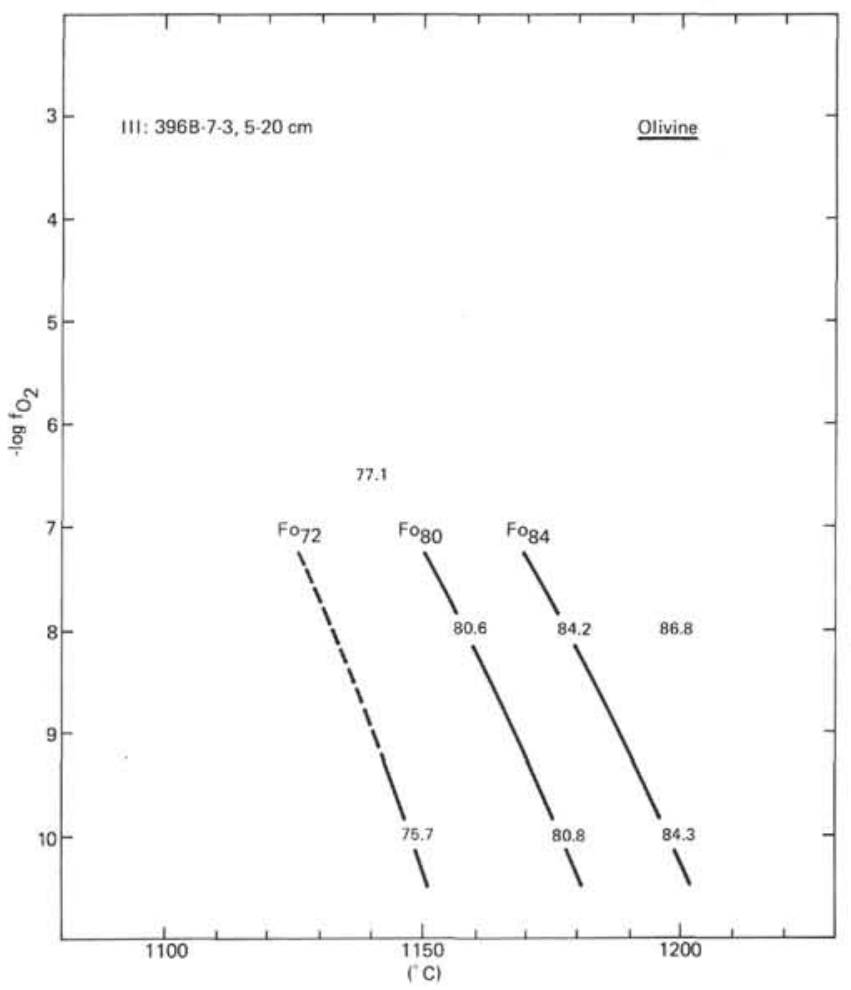

Figure 6. Composition of olivine, Sample 7-3, $5-20 \mathrm{~cm}$.

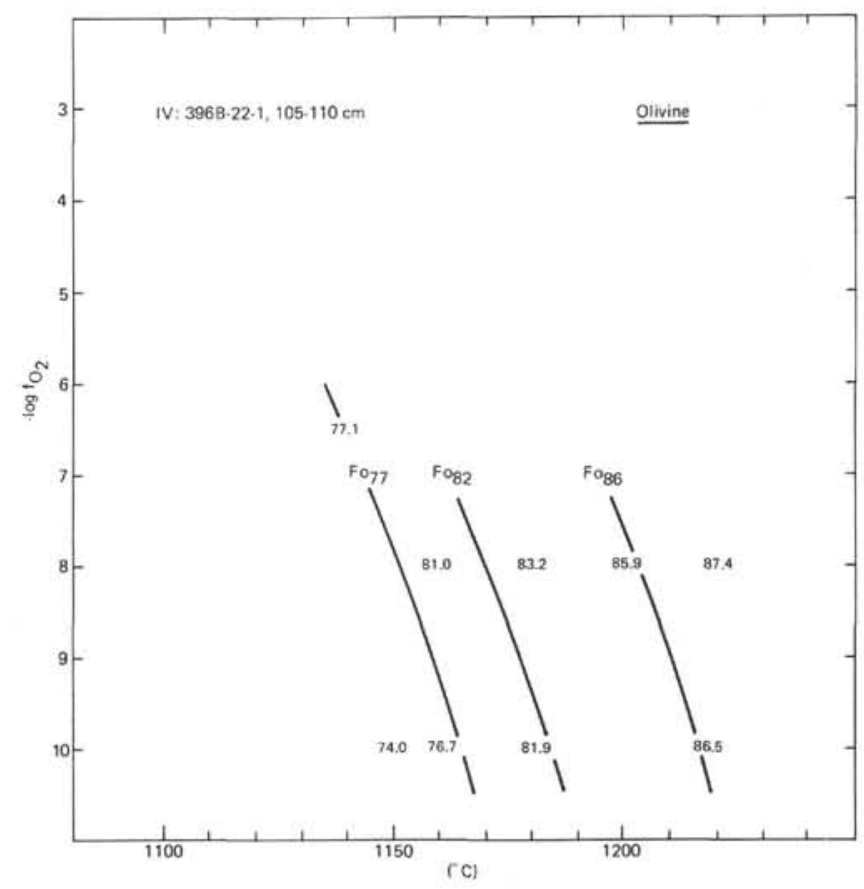

Figure 7. Composition of olivine, Sample 22-1, 105-110 $\mathrm{cm}$. 


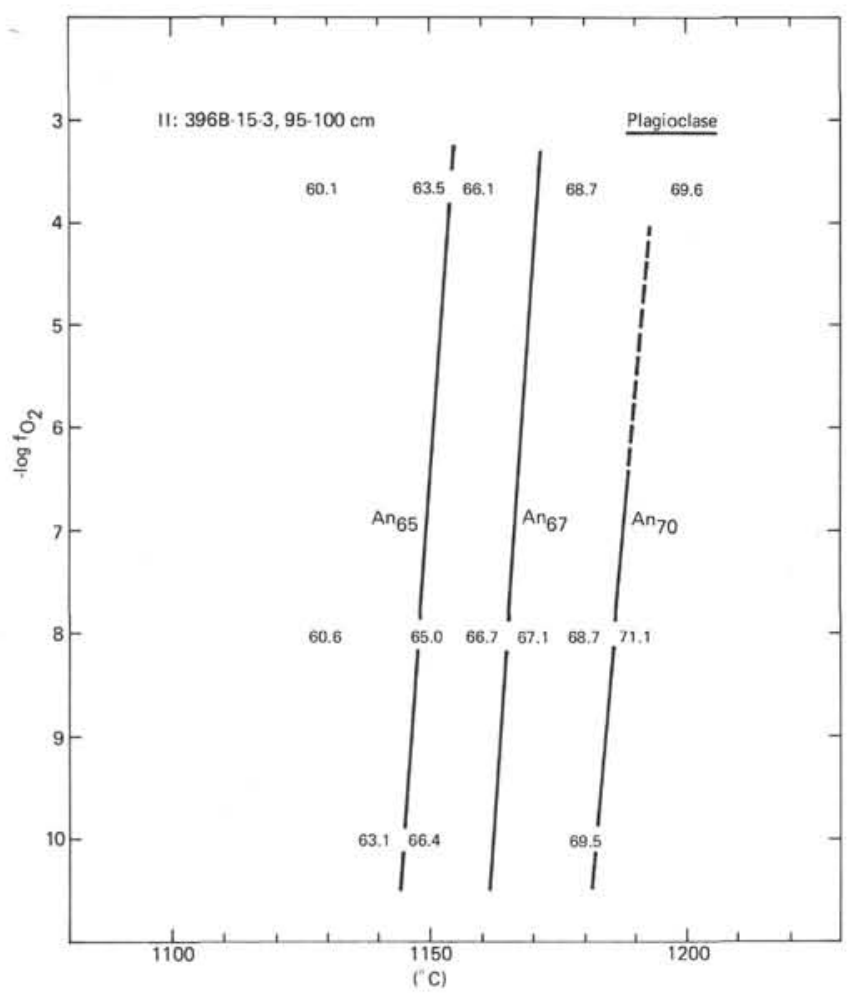

Figure 8. Composition of plagioclase, Sample 15-3, 95-150 $\mathrm{cm}$.

\section{CONCLUDING REMARKS}

By comparing the experimental results with the natural phase relations, we draw the following conclusions.

For Sample 15-3, 95-100 cm basalt, the temperature of magma eruption was about $1195^{\circ} \mathrm{C}$, and olivine and plagioclase crystallized as groundmass minerals. The oxygen fugacity of the magma at the time of eruption was near $10^{-8}$, on the basis of the similar chemical compositions of olivine and plagioclase in experimental and natural specimens.
For Sample 7-3, $5-20 \mathrm{~cm}$ basalt, the temperature of the magma at the eruption was about $1210^{\circ} \mathrm{C}$, and the oxygen fugacity of the magma was also near $10^{-8}$

For Sample 22-1, 105-110 cm basalt, direct comparison is impossible, because the basalt contains plagioclase phenocrysts in considerable amounts. As discussed in the earlier section, the basalt may be derived by mixing of plagioclase and liquid. The Sample 22-1, $105-110 \mathrm{~cm}$ basalt may have been erupted at temperatures of about $1190-1200^{\circ} \mathrm{C}$ and at $\mathrm{fO}_{2}$ around $10^{-8}$, by the comparison of olivine compositions.

The above conclusions are obtained on the assumption that the pressure and the amount of volatile component, if any, do not influence the phase relation. The assumption may be reasonable for the tholeiitic magma erupted at the deep ocean floor.

\section{ACKNOWLEDGMENTS}

The authors are indebted to Dr. Sato, of Kanazawa University, who donated the core samples used in the experiment, and to Prof. Kushiro, of the University of Tokyo, who reviewed the manuscript.

\section{REFERENCES}

Hill, R. and Roeder, P., 1974. The crystallization of spinel from basaltic liquid as a function of oxygen fugacity, J. Geology, v. 82 , p. 709-729.

Hodges, F.N. and Bender, J.F., 1976. Petrogenesis of basalt glass from project FAMOUS: experimental study from $1 \mathrm{~atm}$. to 15 kbar., G.S.A. annual meeting, abstract.

Kushiro, I. and Thompson, R.N., 1972. Origin of some abyssal tholeiites from the Mid-Atlantic Ridge, Carnegie Inst. Wash. Yearbook, v. 71, p. 403-406.

Presnall, D.C. and Brenner, N.L., 1974. A method for studying iron silicate liquids under reducing conditions with negligible iron loss, Geochim. Cosmochim. Acta, v. 38, p. 1785-1880.

Shido, F., Miyashiro, A., and Ewing, M., 1971. Crystallization of abyssal tholeiites, Contr. Mineral. Petrol. v. 31, p. 251-266.

Tilley, C.E., Thompson, R.N., and Lovenbury, P.A., 1972. Melting relations of some oceanic basalts, Geol. J., v. 8, p. 59-64. 